\title{
5. 胃食道逆流症と呼吸器疾患一心身障害児医の立場から
}

\author{
北住 映二 \\ (心身障害児総合医療療育センター小児科)
}

脳性麻瘏等の障害児において，重度になるほ ど, 長期仰臥位, 笳緊張宇進, 上気道閉塞性呼 吸障害, 脊柱側弯等の要因が複合して, 胃食道 逆流症（GERD）が発症・悪化し, 呼吸障害と の悪循環を形成してくる。障害児の GERDに ついて，症例を紹介しながら要点を述べた。

【1】GERによる痙攀様症状 (Sandifer's 症候 群）のみならず，障害児にしばしば見られる不 眠, 不機嫌, 啼泣, 筋緊張立進等の基礎として GERがある可能性に留意を要する。【2】 嘔吐や逆流性食道炎症状が目立たず, 呼吸器症 状を主体とするGERDのグループもあること への充分な留意が必要である。特に, 反復性の 咳, 喘鳴などが, 食事摄取や注入との時間的関 連や姿勢による変化を伴って出現する場合は, 嘔吐や上部消化管出血が軽くても，GERDによ る場合がある。【3】十二指腸通過障害や腸 管回転異常等による二次性GERの可能性につ き，充分に検索・留意する必要がある。これら

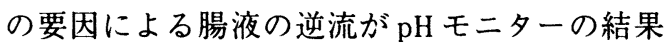
に影響する可能性にも留意が必要である。

【4】機能的要因と構造的要因による日常的な 上気道狭窄（上気道透視が動的な状態把握に有 用）が，呼吸障害の大きな要因となると共に GERの誘因となっている場合がかなりある。 この場合, 経鼻咽頭エアウェイの日常的使用, 姿勢管理, 気管切開, CPAPなどによる, 上気 道狭窄・閉塞への積極的な対応が奏功すると, GERD の改善も得られる場合がかなりある。強
い上気道閉塞性呼吸障害への対応が不充分なま ま逆流防止手術が行われた場合は, GERの改 善が不良であり得る。【5】治療として, 姿 勢管理が, GERへの直接の影響および，呼吸 障害の改善による GERの改善という意味で, 重要であり, 理学療法士等の関与や, 腹臥位マッ ト, U 型マット等の利用により, 腹臥位や前傾 姿勢を取ることが有効である。右側臥位は GER を悪化させる傾向があり注意が必要であ る。【6】重度の鱟下障害も伴う場合, GER が関与しての重度の肺炎, 肺膿瘍等のリスクが 高まるので早めの手術治療を考慮すべきであ る。また, 左凸側弯が進行すると GERも悪化 していく可能性が高いので, 手術を早めに検討 する必要がある。【7】しかし, 唾液の誤嚥 も多いような重症ケースでは逆流防止手術後も 誤嚥性肺炎を反復し, 逆流防止手術が QOL の 改善に至らない場合があり, 誤嚥防止のための 手術的治療（喉頭気管分離手術等）が先行して 検討されるべきである。【8】経鼻空腸力 テーテル栄養法が, 手術前の対応, 手術困難例 · 術後再発例への対応として，有用である。逆流 防止手術だけでなく胃瘦から空腸へ挿入したカ テーテルからの投与, 腸瘦造設等, さまざまな バリエーションを持った対応工夫が障害児では 必要とされる。(参考ビデオ〈重症児とともに・ 応用編，1.呼吸障害への取り組み。2. 誤嚥 胃食道逆流症などへの対策〉北住映二・鈴木康 之制作担当，全国重症心身障害児を守る会) 